\title{
Local production and international trade regulations: challenges and legal framework
}

\author{
By Violla Nabawanda*
}

\begin{abstract}
This paper discusses local production and international trade regulations that is the legal framework and challenges encountered in ensuring compliance with such trade regulations. It contextualizes the meaning of local production and its benefits. This paper further discusses the key international trade regulations such as the World Trade Organisation (WTO) which was created out of the General Agreement on Tariffs and Trade (GATT). At regional level specifically Africa, this paper discusses the African Continental Free Trade Area Agreement (AfCFTA) whose main focus is to establish a free trade area. Furthermore, this paper discusses the challenges encountered in ensuring that local production by African countries is in compliance with the international and regional trade regulations.
\end{abstract}

\section{A. INTRODUCTION}

Local production doesn't have a specific definition but would literally refer to the domestic production of goods and services within a country for either domestic consumption or export. Local production is usually referred to life enhancing products produced in countries in which they are to be maximized for social and economic value. The strategy with sensitivity to place and scale in order to sustain local communities and provide new job opportunities while preserving the quality of the environment. Before, most countries in Africa produced for domestic consumption and where there were exports, it was mainly within the continent. However, the world has become more integrated in a very complex way. Most goods now produced in Africa are destined for international markets though most of the exports are in raw form (raw materials). ${ }^{1}$ Such being crude oil, gold, copper, nickel, cocoa beans, coffee, hides and skin, vegetables and fruits amongst others. On the other hand, most of these counties import manufactured commodities being apparatus, electrical machinery, textile yarn, motor vehicles and bicycles, medicines, chocolate, refines

* The author holds a Master of Laws from the University of Dar es Salaam in cooperation with the University of Bayreuth with a Focus on East African Community Law and Regional Integration Law: Post Graduate Diploma in Legal Practice-The Law Development Centre (awaiting award): Post Graduate Diploma in Tax and Revenue Administration-The East African School of Taxation: Bachelor of Laws degree (Honors)-Uganda Christian University Mukono. Email: vnabawanda@gmail.com

1 Valid Nutrition http://www.validnutrition.org/local-production/. 
sugar and other modern related technologies. ${ }^{2}$ But as of today, due to the covid 19 pandemic, the economies both locally and internationally have been substantially constrained.

Local production is associated with a number of benefits such as the development of the indigenous food industry by supporting the local value chain to supply their produce for the manufacturing of our food products. This in turn, enhances additional farming skills, Knowledge and skills transfer on quality food manufacturing, Easier and quicker distribution of the food as consumers are closer to the producers, In many instances, better marketing of the products as they are made from locally available raw materials which have the preference of the population (that is taste is already known and accepted), Less storage time, therefore diminished warehousing costs and food losses, and Direct economic benefits through greater incomes for local farmers and more financial contributions to local economies; and increased employment levels - both direct and indirect, a multiplier effect.

\section{B. INTERNATIONAL TRADE REGULATIONS}

\section{International Legal Framework}

The exchange of goods and services in international trade is subject to an array of laws, regulations, and restriction. On the international forum, the Agreement Establishing the World Trade Organisation (WTO) is the most recognized international trade instrument. The WTO succeeded the General Agreement on Tariffs and Trade (GATT) in the expectation that it will be replaced by a specialized agency of the United_Nations (UN) to be called the International Trade Organization (ITO). ${ }^{3}$

\section{World Trade Organisation (WTO)}

What is the World Trade Organisation?

The WTO began around the $01^{\text {st }}$ January 1995 , but its trading system is half a century older. Since 1948, the General Agreement on Tariffs and Trade (GATT) had provided the rules for the system. (The second WTO ministerial meeting, held in Geneva in May 1998, included a celebration of the $50^{\text {th }}$ anniversary of the system). It did not take long for the General Agreement to give birth to an unofficial, de facto international organization, also known informally as GATT. Over the years, GATT evolved through several rounds of negotiations. The last and largest GATT round, was the Uruguay Round which lasted from 1986 to 1994 and led to the WTO's creation. Whereas GATT had mainly dealt with trade in goods, the

2 Nahanga, Verter. International Trade: The Position of Africa in Global Merchandise Trade. September $13^{\text {th }}, 2017 \mathrm{http}: / / \mathrm{www}$.intechopen.com/chapters/55353/.

3 World Trade Organisation: International Trade https://www.britannica.com/topic/World-Trade-Orga nization/. 
WTO and its agreements now cover trade in services, and in traded inventions, creations and designs (intellectual property). ${ }^{4}$

\section{Main Objective of the WTO}

The main overriding objective of the WTO is to ensure that trade flows as smoothly, predictably and freely as possible. (Emphasis is placed on the Preamble to the Agreement Establishing the World Trade Organisation). This objective can simply be elaborated further into six (6) key main objectives. That is to set and enforce rules for international trade; to provide a forum for negotiating and monitoring further trade liberalization; to resolve trade disputes; to increase the transparency of decision-making processes; to cooperate with other major international economic institutions involved in global economic management; and to help developing countries benefit fully from the global trading system. Much as these objectives were shared by the GATT, in practice they have been mostly pursued comprehensively by the WTO. For example, whereas the GATT focused almost exclusively on goods with the exclusion of agriculture and textiles, the WTO encompasses all goods, services, and intellectual property, as well as some investment policies. ${ }^{5}$

\section{Membership of the WTO}

The WTO comprises of both members and observers. The WTO membership comprises of over 164 countries representing $98 \%$ of world trade, while it has 25 observers. In the East Africa region, all the Partner States of the East African Community that is the Republic of Uganda, Republic of Kenya, United Republic of Tanzania, Republic of Rwanda, and Republic of Burundi are members of the WTO with the exception of the Republic of South Sudan which is an observer government. Also, the People's Republic of China joined the WTO in $2001 .^{6}$

\section{Functions of the WTO}

WTO functions as a central body that facilitates global trade between nations. That is, it deals with global trade rules. Its functions are provided for under Article III of the Agreement Establishing the World Trade Organisation.

4 https://www.wto.org/english/thewto_e/whatis_e/tif_e/fact1_e.htm/.

5 World Trade Organisation: International Trade https:/www.britannica.com/topic/World-Trade-Orga nization/.

6 Understanding the WTO: The Organisation http://www.wto.org/english/thewto_e/whatis_e/tif_e/org 6_e.htm/. 
a) Administering WTO trade agreements

At its heart are the WTO agreements, negotiated and signed by the bulk of the world's trading nations. These documents provide the legal ground-rules for international commerce. They are essentially contracts, binding governments to keep their trade policies within agreed limits. Although negotiated and signed by governments, the goal is to help producers of goods and services, exporters, and importers conduct their business, while allowing governments to meet social and environmental objectives.

The system's overriding purpose is to help trade flow as freely as possible - so long as there are no undesirable side-effects - because this is important for economic development and well-being. That partly means removing obstacles. It also means ensuring that individuals, companies and governments know what the trade rules are around the world, and giving them the confidence that there will be no sudden changes of policy. In other words, the rules have to be "transparent" and predictable. ${ }^{7}$

b) Handling trade disputes - the WTO is the multilateral undertaking in dispute resolution

The WTO's procedure for resolving trade conflicts under the Dispute Settlement Understanding is vital for enforcing the rules and therefore ensuring that trade flows smoothly. Governments bring disputes to the WTO if they think their rights under the WTO agreements are being infringed. Judgments by specially appointed experts are based on interpretations of the agreements and individual members' commitments. The system encourages members to settle their disputes / differences through consultation with each other. If this proves to be unsuccessful, they can follow a stage by stage procedure that includes the possibility of a ruling by a panel of experts and the chance to appeal the ruling on legal grounds. This confidence has been borne out by the number of cases brought to the WTO. That is more than 600 cases have been attended to by WTO since its establishment in 1995 compared to the 300 disputes dealt with during the entire life of the GATT (1947-94). It's important to note that African countries rarely declare trade disputes.

\section{c) Forum for trade negotiations}

The WTO is an organization for liberalizing trade. It's a forum for governments to negotiate trade

agreements. It's a place for them to settle trade disputes. It operates a system of global trade rules. These rules of trade provide assurance and stability. Consumers and producers know they can enjoy secure supplies and greater choice of finished products, components, raw materials and services they use. Producers and exporters get to know that foreign markets are and will remain open to them.

7 Understanding the WTO: Basics, what is the World Trade Organisation? https://www.wto.org/englis h/thewto_e/whatis_e/tif_e/fact1_e.htm/ 
Above all, the WTO is essentially a negotiation forum. It is a place where member governments go, to try to sort out the trade problems they face with each other. The first step is to talk. The WTO was born out of negotiations, and everything the WTO does is the result of negotiations. The bulk of the WTO's current work comes from the 198694 negotiations called The Uruguay Round and earlier negotiations under The General Agreement on Tariffs and Trade (GATT). The WTO is currently the host to new negotiations, under the "Doha Development Agenda" launched in 2001. It's also important to note that where countries have faced trade barriers and wanted them lowered, the negotiations have helped to liberalize trade. But the WTO is not just about liberalizing trade, and in some circumstances its rules support maintaining trade barriers.

\section{d) Monitoring national trade policies}

The WTO monitors national trade policies through building trade capacity in developing economies. Over three-quarters of WTO members are developing or least developed economies. All WTO agreements contain special provisions for them, including longer time periods to implement commitments, measures to increase their trading opportunities and support to help them build the infrastructure needed to participate in world trade. A WTO Committee on Trade and Development looks at developing economies' special needs. Its responsibility includes implementation of the WTO agreements, technical cooperation and the increased participation of developing economies in the global trading system.

The WTO members have developed vast trade initiatives to assist developing economies. Such being the Aid for Trade Initiative launched in 2005 with the aim of helping developing economies build trade capacity, enhance their infrastructure and improve their ability to benefit from trade opening opportunities. A global review of the initiative is held every two years at the WTO headquarters in Geneva, Switzerland.

There is also the Enhanced Integrated Framework (EIF) being the only multilateral partnership dedicated exclusively to assisting Least Developed Countries (LDCs) in their use of trade as an engine for growth, sustainable development and poverty reduction. It's a partnership of 51 countries (with the all EAC Partner States inclusive with the exception of Kenya), 24 donors and 8 partner agencies including the WTO, working closely with governments, development organisations, civil society and academia. Another is the Standards and Trade Development Facility (STDF) which was set up to help developing economies meet international standards for food safety, plant and animal health and access to global markets.

e) Technical assistance and training for developing countries

The WTO organizes hundreds of technical cooperation missions to developing economies annually. It also holds many trade policy courses each year in Geneva for government officials. Regional seminars are also held regularly in all regions of the world with a special 
emphasis on African countries. For example, in 2019, over 22,800 participants benefited from WTO training aimed at improving understanding of WTO agreements and global trade rules.

f) Cooperation with other international organizations

Article V of the WTO Agreement provides that the General Council shall make appropriate arrangements for effective cooperation with other intergovernmental organisations that have responsibilities related to those of the WTO. That it may also make appropriate arrangements for consultation and cooperation with non-governmental organisations concerned with matters related to those of the WTO.

\section{REGIONAL LEGAL FRAMEWORK}

At the African level, the Agreement Establishing the African Continental Free Trade Area is widely seen as a crucial driver for economic growth, industrialization and sustainable development in Africa despite the opportunities and challenges that need to be addressed. The African Continental Free Trade Area is the continent's most ambitious integration initiative, and is also one of the Africa's Agenda 2063 flagship projects. ${ }^{8}$

The African Continental Free Trade Area Agreement (AfCFTA) is a free trade agreement that was signed by 44 out of a total of 55 African countries in Kigali, Rwanda on the $21^{\text {st }}$ March 2018, at the $10^{\text {th }}$ Extraordinary Summit of the African Union to establish a free trade area across the African continent and came into force on the $30^{\text {th }}$ May 2019. Once fully implemented, AfCFTA will be the largest free trade area in the world. It suffices to note that most members of the AfCFTA are also members of the World Trade Organisation.

Prior to this Agreement, there are and were various existing economic communities within the African continent which are officially recognised as building blocs for the AfCFTA. These include the Arab Maghreb Union (AMU); the Common Market for Eastern and Southern Africa (COMESA); the Community of Sahel-Saharan States (CEN-SAD); the East African Community (EAC); the Economic Community of Central African States (ECCAS); the Economic Community of West African States (ECOWAS); the Intergovernmental Authority on Development (IGAD) and the Southern African Development Community (SADC).

It is expected that the Agreement once fully implemented, will boost manufacturing and by 2035 vision, will contribute to the reduction in number of people living in extreme poverty by 30 million and people living in moderate poverty by 68 million. Other gains expected from this Agreement are increase in real income by US $\$ 450$ billion; increase the volume of total exports by $29 \%$; intracontinental exports to increase by more than $81 \%$ and exports outside the African continent by $19 \%$; increase employment opportunities and

8 The African Continental Free Trade Area; A tralac guide. Trade Law Centre, $7^{\text {th }}$ Ed, August 2020. 
wages for both skilled and unskilled workers. Most gains are expected within the manufacturing sector, followed by agricultural sector and modest gains from trade in services. ${ }^{9}$

Countries that have so far which ratified the Agreement include: Algeria, Angola, Burkina Faso, Cameroon, Chad, Republic of Congo, Côte d'Ivoire, Djibouti, Egypt, E-Swatini, Equatorial Guinea, Ethiopia, Gabon, Ghana, Guinea, Kenya, Mali, Mauritania, Mauritius, Namibia, Niger, Rwanda, Saharawi Republic, São Tomé and Príncipe, Senegal, Sierra Leone, South Africa, Kenya, The Gambia, Togo, Uganda and Zimbabwe.

\section{Scope of the Agreement}

The Agreement comprises of Protocols on Trade in Goods; Protocol on Trade in Services; Protocol on Rules and Procedures on the Settlement of Disputes. In addition, the Protocol on Investment, Protocol on Intellectual Property Rights and Protocol on Competition will be formulated in subsequent phases of implementation.

Generally, the Agreement covers reduction of tariffs among member countries; trade facilitation policies including those relating to investment and intellectual property rights protection; regulatory measures across the African continent to establish standards and counter technical barriers to trade.

The policy areas covered by this Agreement include tariffs on manufactured and agricultural goods; export taxes; customs; competition policy; anti-dumping; counter veiling measures; State Trading Enterprises; technical barriers to trade; sanitary and phytosanitary measures; movement of capital; intellectual property rights; and investment.

\section{Objectives of the AfCFTA}

The Agreement provides for both general and specific objectives. These are provided for under Articles 3 and 4 respectively. These can be summarized as follows; that is to create a single continental market for goods and services, with free movement of business persons and investments; to expand intra-Africa trade across the regional economic communities and the continent in general; and to enhance competitiveness and support economic transformation. ${ }^{10}$

\section{Key Principles Governing the AfCFTA}

The Agreement will be governed by various principles including those commonly applicable to other preferential trade areas and these include: Most-Favored-Nation (MFN) Treatment; reciprocity; substantial liberalization; transparency and disclosure of informa- 
tion; consensus in decision-making; national treatment; flexibility, special and differential treatment.

Implementation of the Agreement

Implementation will be done in a phased manner with Phase I focusing on liberalization of trade in goods and services and specifically eliminating tariffs on $90 \%$ of product categories and establishing a framework for dispute settlement. Phase II of implementation will focus on establishing competition and investment policies, and intellectual property rights protection. It is expected that the AfCFTA will culminate into a customs union at a later stage.

Institution Framework for Implementation

The African Union Assembly which comprises of all African Union Heads of State and Government will provide oversight on the implementation of the Agreement and is also the decision-making body for the AfCFTA. Other bodies involved in the implementation of the Agreement are the Council of Ministers comprised of Ministers for Trade or other nominees from State Parties; the Committee of Senior Trade Officials comprised of Permanent Secretaries or other officials from participating countries; The AfCFTA Secretariat which is the administrative organ responsible for coordination of implementation; and the Dispute Settlement Mechanism to handle disputes involving participating countries.

Dispute Mechanism under the AfCTA - Article 20

The AfCFTA has a dispute settlement system modelled on the Dispute Settlement Understanding of the WTO and consists of Panels and an Appellate body which facilitate consultations, conciliation, mediation, as well as arbitration for dispute settlement. $\underline{\text { Article }}$ 20 read verbatim states that a Dispute Settlement Mechanism is hereby established and shall apply to the settlement of disputes arising between State Parties. That the Dispute Settlement Mechanism shall be administered in accordance with the Protocol on Rules and Procedures on the Settlement of Disputes where the latter shall establish, inter alia, a Dispute Settlement Body. For a dispute to arise according to the Protocol, there has to be a disagreement between State Parties regarding the interpretation and/or application of the Agreement in relation to their rights and obligations. Thus only State Parties can have access to dispute settlement under the AfCFTA. Private parties such as exporters, importers, and service providers amongst others do not, in their own right, have access to the AfCFTA dispute settlement system. However, such private parties can only be protected if a State Party, able to show that its rights have been violated, brings a claim.

Furthermore, an individual can't compel a State Party to fulfill its obligations under the Agreement. However, such individual can seek Court's redress where they allege that 
there is breach of a right and that such right has been violated by a State Party which is a party to it. In the locus clascus case of Polytol Paints \& Adhesives Manufacturers Co. Ltd vs. The Republic Of Mauritius; ${ }^{11}$ Court determined a number of issues that were brought before it by the Applicant. One of the issues to be determiend by the Court was whether there was breach of the Treaty as the Applicant raised a number of allegations that were breached by Mauritius. Under this issue, the Applicant alleged that Mauritius failed to fulfill its obligations under the Treaty as required. Court analysed this issue whilst relying on Article 26 of the Treaty. Article 26 states that any person who is resident in a Member State may refer for determination by the Court the legality of any act, regulation, directive or decision of the Council or of a Member State on the grounds that such act, directive, decision or regulation is unlawful or an infringement of the provisions of this Treaty...

Therefore, a legal or natural person is only permitted to bring to Court matters relating to conduct or measures that are unlawful or an infringement of the Treaty but not the non-fulfillment of a Treaty obligation by a Member State. The responsibility of bringing a matter relating to non-fulfillment of Treaty obligations is reserved for Member States and the Secretary General as evidenced under Articles 24 and 25. Article 24 (1) states that $a$ Member State which considers that another Member State or the Council has failed to fulfill an obligation under this Treaty or has infringed a provision of this Treaty, may refer the matter to the Court. The Treaty further under Article 24 (2) gives the same right to a Member State as given to a legal or natural person in Article 26.

With regard to the Secretary General, Article 25 of the Treaty confers on him or her an obligation to take measures to deal with a matter where he or she considers that a Member State has failed to fulfill an obligation under the Treaty or has infringed a provision of the Treaty. Such measures involve engaging the Member State concerned if that fails to remedy the situation, refer the matter to the Bureau of the Council which may decide that the matter be referred to the Court immediately or be referred to Council and if it is not resolved, the Council must direct the Secretary General to refer it to the Court.

In conclusion while looking at Articles 24, 25 and 26, it is clear that the intention in the Treaty is to reserve matters relating to non-fulfillment of Treaty obligations to Member States and the Secretary General. Therefore, the Applicant had no right to refer such matter to the Court for determination as Court needed not decide on the questions raised by the Applicant relating to the alleged failure by Mauritius to implement the Treaty within its domestic legislation, failing to give the Treaty force of law.

It suffices to note that much as there the Agreement is alive to the fact that there will be trade disputes, most African governments do not declare trade disputes. That is there are less trade disputes between member states in Africa as compared to other countries on the globe.

11 Reference No.1 of 2012; In the COMESA Court of Justice, First Instance Division-Lusaka, Zambia where Lord Principal Judge Samuel Rugege delivered the judgment of the Court. 


\section{Opportunities in AfCFTA}

Generally, intra-African trade, has over time been much lower in comparison with intraregional trade in other regions for example America, Asia, Europe and Oceania. The foregoing notwithstanding, some of the regional trading blocs have grown in strength and yielded positive results over the years. In 2019, Kenya's imports from countries within the African region were mainly from the Republic of South Africa; Egypt; Uganda, Tanzania, E-Swatini and Mauritius and Kenya exports were mainly to Uganda, Tanzania, Rwanda, Egypt, Congo and Somalia. Kenya's major imports were mineral fuels, mineral oils, and their products and mineral waxes and major exports were coffee, tea, mate, spices, cut flowers.

The AfCFTA offers greater access to a wider market, various business and partnership opportunities for economic growth within the African continent. Increased intra-African trade is expected to promote competitiveness within the manufacturing sector and industries, spur infrastructure development and technology transfer across countries within the region.

\section{CHALLENGES ASSOCIATED WITH LOCAL PRODUCTION IN ENSURING COMPLIANCE WITH INTERNATIONAL TRADE REGULATIONS}

\section{Introduction}

Africa's challenges in trade both at regional and international level are legion and well documented. Economists commonly argue that poor countries suffer from a development 'vicious circle' the predominance of subsistence production which inhibits accumulation of savings; low savings meaning low investment; low consumption further which inhibits investment; and because investment is low, economic growth is stagnant. ${ }^{12}$

\section{Challenges}

The effects and scourge of the Covid 19 pandemic which is and contiunes to be a humanitarian global crisis. According to the WTO, ${ }^{13}$ the COVID-19 pandemic represents an unprecedented disruption to the global economy and world trade, as production and consumption are scaled back across the globe. However, amidst the efforts to try and develop a vaccine, it has continued to present daunting challenges to governments as well as international organisations. The pandemic has caused massive economic im-

12 UNCTAD, The Least Developed Countries Report, Overview. Geneva, May 2004. See especially pp. 2-3. Paul Collier's celebrated book, The Bottom Billion: Why the poorest countries are failing and what can be done about it, New York: Oxford University Press, 2007, is the most accomplished elaboration of the 'trap' argument.

13 WTO reports on COVID-19 and world trade. https://www.wto.org/english/tratop_e/covid19_e/cov id_reports_e.htm/. 
pacts that threaten to undo decades of recent progress in spheres of poverty reduction, child nutrition and gender equality amongst others. it has further exacerbated efforts to support refugees, migrants, and other vulnerable communities globally. ${ }^{14}$

Tariff and non-tariff measures as well as technical and non-technical measures are amongst some of the major key trade restrictions and constraints of trade especially for Africa's agricultural produce. That is Least Developed African countries increase tariffs so as to raise revenue and also protect infant industries. On the other hand, developed nations increase tax to curb trade so as to protect domestic producers from global competition. ${ }^{15}$

Restrictive regulations of commerce such as red tape ${ }^{16}$ and bureaucracy, policies, abuse of standards of safety amongst others.

High levels of corruption. For example, corruption permeates all parts of Ugandan society and acts as a major constraint on economic development and poverty reduction. $38 \%{ }^{17}$ of people had to pay a bribe to access a public service in the previous year. Uganda's legal framework for fighting corruption is relatively strong that is several new anti-corruption laws having been passed, but implementation of these laws is weak, especially for cases of grand corruption. ${ }^{18}$

The complexity of International trade agreements and the multitude of documentation involved. Most of these agreements need to be studied by experts in trade and be able to guide on the best policy to be adopted. However, the complexity of these agreements in terms of language that is being used and the conditions and terms that need to be fulfilled make it nearly impossible especially for least developed countries. It is further exacerbated by the multitude of documentation involved that has to be read, understood and presented for consent by any country wishing to involve itself in trade on the world market.

Political climate between and within countries i.e. Rwanda and Uganda tensions, and there seems no path to making peace again after two years of katuna border closure; the recent 2021 South Africa uprisings after the arrest of former leader Jacob Zuma. There was a lot of looting and many businesses were greatly affected for example shopping malls. Also the military coup in Mali; and Ethiopia uprisings amongst others.

14 How covid 19 is changing the world: a statistical perspective, Volume III, CCSA publication. Released 30 ${ }^{\text {th }}$ March $2021 \mathrm{https} / /$ www.wto.org/english/tratop_e/covid19_e/ccsa_publication_vol3 e.pdf/.

15 Supra Note 2.

16 Red tape is a derisive term for excessive regulation or rigid conformity to formal rules that are considered redundant or bureaucratic and hinder or prevent action or decision-making https://econ omictimes.indiatimes.com/et-empower/what-is-red-tape/articleshow $/ 2613130 . \mathrm{cms}$ ?from=mdr/.

17 Rosie, Sharpe. Uganda: Overview of corruption and anti-corruption. Anti-Corruption Resource Centre and Transparency International. U4 Helpdesk Answer 2018:26, 22 May 2018. https://www. u4.no/publications/uganda-overview-of-corruption-and-anti-corruption-2018/.

18 Ibid. 
Low levels of technological advancement and skill considering that the world is a growingly predominant technological sphere. For example, internet costs, slow bandwidth amongst others.

Low profit earnings by foreign investors within Africa due to the difficult business environment. That is the markets are small and not strategic. For example, as of 2021, Shoprite and Games stores have existed Uganda with no exception of Kenya and Tanzania which are all East African member states; and other African countries where it was operating. ${ }^{19}$

Some African countries are landlocked which advancly affects international trade tremendously. For example, Uganda being a landlocked country, most of its imports and exports have to come through Mombasa.

High transport costs within and outside the bounder areas coupled with poor infrastructure coupled with climate change. The costs of moving goods within countries are generally higher in developing countries than in the rest of the world. This is especially true in much of Africa. Transport in Africa is often unpredictable and unreliable, and the cost of transport is in most cases higher than the value of the goods being transported. ${ }^{20}$ The high cost of getting goods to and from borders or ports in Africa is therefore greatly restricting the continent's potential gains from international trade. ${ }^{21}$

Insecurity across the borders such as the constant killing of Ugandan and Kenyan traders in South Sudan and yet these are member states of the one regional body which is the East African Community.

Due to the existing and overlapping memberships of AfCTA participating countries in other regional economic bodies also affects international trade. AfCTA participating countries may find themselves in a difficult position of conflicting obligations or prioritization of their obligations under other regional bodies over obligations under the AfCTA.

\section{Conclusion}

International trade is one of the avenues through which countries come together and carry out trade through the exchange of different goods and services as imports and exports. These avenues of trade are however governed by different international trade regulations whose main emphasis is to regulate trade through having fair policies and processes. How-

19 Brian, Ngugi. South African retail store Game to exist East African Market. The East African. WEDNESDAY SEPTEMBER 012021 https://www.theeastafrican.co.ke/tea/business/south-africa -retail-store-game-to-exit-east-african-market-3534192/.

20 Donaldson, D; Jinhage, A and Verhoogen, E. Beyond Borders: Making transport work for African Trade. 30 ${ }^{\text {th }}$ March 2017 https:/www.theigc.org/reader/beyond-borders-making-transport-work-for -african-trade/key-message-1-high-cost-getting-goods-borders-ports-africa-restricting-continents-p otential-gains-international-trade/.

21 Ibid 
ever, there are a multitude of complexities that have hindered the failure to observe of these international trade regulations. This is because the countries involved in such trade dealings are either developed or least developed, with each having a different interest on why its engaging in trade. Furthermore, the developed countries still desire to maintain trade monopoly which has quite made it difficult for the least developed countries to penetrate such international market so as to compete favourably. This has been greatly attributed to the advanced technologies that are now being employed by the modern economies as compared to the growing African market which is still struggling with the ever increasing technological advancement. 